\title{
Faith-Inspired Muslim Parents' School Choices and Attitudes in the Cultural West and Australia
}

\author{
Derya Iner
}

check for updates

Citation: Iner, Derya. 2021.

Faith-Inspired Muslim Parents School Choices and Attitudes in the Cultural West and Australia. Religions 12: 746. https://doi.org/10.3390/ rel12090746

Academic Editors: Enzo Pace and Klaus Baumann

Received: 13 April 2021

Accepted: 6 September 2021

Published: 10 September 2021

Publisher's Note: MDPI stays neutral with regard to jurisdictional claims in published maps and institutional affiliations.

Copyright: (C) 2021 by the author. Licensee MDPI, Basel, Switzerland. This article is an open access article distributed under the terms and conditions of the Creative Commons Attribution (CC BY) license (https:// creativecommons.org/licenses/by/ $4.0 /)$.
Centre for Islamic Studies and Civilisation, Charles Sturt University, Sydney 2144, Australia; diner@csu.edu.au
Abstract: All parents want the best accessible, available and affordable school for their children. Yet, the literature highlights that school choice for middle-class parents in the cultural West is a deliberate decision and a reflection of their salient identities. For racialised middle-class Western parents, school choice is an instrumental investment to secure social upward mobility and minimise the harms of racism for their children. Research focusing on Western middle-class Muslim parents highlights that accommodation of Muslim identities and ethno-religious values is pivotal in parental school choice. This is expected due to the rise of Islamophobia in the cultural West since 9/11. The semi-structured interviews with faith-inspired middle-class Muslim parents in Australia bring a new dimension to the parental school choice literature. Regardless of carrying more or less similar concerns for their children in an Islamophobic climate, middle-class Muslim parents' school choices vary based on their childhood schooling experiences in the Australian context, diverse parenting styles and mentalities and their children's varying personalities demanding a particular type of school setting. This article demonstrates there is no one size fits all Muslim parent in terms of deciding which school is the best for their children in an Islamophobic climate.

Keywords: school choice; parental school choice; Muslim parents; Islamophobia; Muslim schooling; Muslims in Australia; Islamophobia in schools; parenting styles; faith-inspired Muslim parents

\section{Parental School Choices and Attitudes of Australian Muslims in an Islamophobic Climate}

Parenting is defined in the ecosystem framework as a bridge between the individual and society (Husain 2013). Parents instil their children with a set of family values to navigate social life. Schools facilitate departure from the private family domain and orientation to new social environments as individual entities. Nevertheless, parents' central role in school choice designates the level and type of schools' contribution to the children's adaptation to society.

School choice is perceived as a parental commitment and responsibility (Wolf 2018) by average middle-class parents. However, it carries more value and causes more anxiety among middle-class immigrant parents (Ho 2020) because education for them is key to social upward mobility (Jamal Al-deen 2019) and resistance to racial inequalities (Ho 2020), which have proliferated especially in the absence of social capital. The faith-inspired middle-class Muslim parents in the cultural West, including Australia, share similar anxieties and concerns about the best school choice for their children as Islamophobia continues to increase since 9/11. The cultural West is used in this paper for a group of nations holding Anglo-Christian privileges while sharing more or less a common cultural and historical heritage. Previously known as "the first-world countries", these countries provide economic opportunities and attract immigrants and refugees from around the world including Muslims.

Australia is a multicultural society accommodating over 200 nationalities from around the world (Department of Home Affairs 2020). This diversity is reflected in the Muslim communities as well since the Muslim population in Australia (2.6\%) comes from 183 different countries (Hassan 2018, p. 17). This hyper-diversity is relatively regulated 
with $37.2 \%$ being born and bred in Australia. As a young community, a larger proportion of Muslims in Australia are in full-time education (17\% in contrast to $10 \%$ of Australians as a whole) (Hassan 2018, p. 34).

Regardless of Australia's multicultural discourse in the post-White Australia policy (1949-1973) and relatively higher social cohesion scores, Muslims have remained the most stigmatised community in Australia for decades (Markus 2018). Racism has been directed at Arab and Muslim Australians since the 1991 Gulf War and the 'War on Terror' era of 9/11. Such sentiments are localised further with the in-house racist conflicts such as the Cronulla riots in 2005 (Poynting and Noble 2004; Collins 2007). In the last decade, religious intolerance to Muslims has increased from $21 \%$ to $25 \%$ (11\% to $14 \%$ negative) in contrast to negative opinion towards Christians and Buddhists (ranging between $4 \%$ and 6\%) (Markus 2018 , p. 62). The fearsome Muslim image after $9 / 11$ has been reinforced by media (OnePath Network 2018) and politicians (Akbarzadeh 2016; Cheng 2017). This hostile discourse has sharpened further with the far-right political parties and their increasing popularity on social media (Miller 2017; Hutchinson 2019; Poynting and Briskman 2018; Peucker and Smith 2019). The media and political rhetoric have granted the public "permission to hate" (Poynting and Perry 2007) and led to an increase in everyday Islamophobia. This problematises Muslim identity by conflating ordinary Muslims with terrorists and associating them with so-called Orientalist inferiorities (Skenderovic and Späti 2019).

Everyday Islamophobia especially targets Muslim women and their children. According to the Islamophobia in Australia report-II, 72\% of victims were women while $71 \%$ of perpetrators were men, $96 \%$ of the victim women were wearing a hijab (headscarf) and $11 \%$ of the victim women were with their mostly pre-school children at the time of the incident (Iner et al. 2019).

As visible markers of Islam with their hijab, Muslim mothers draw hate to their children (Iner et al. 2019) and expressed their worry for that in the interviews conducted for this study. If not directly, Muslim children are exposed to Islamophobia indirectly through the incidents faced by their hijabi mothers, sisters, female family members or family friends.

Harassment of Muslims continues online as well. Close to 2500 Australian children aged 12-15 admit the most common hate type they are exposed in the cyber world is anti-Muslim hate (53\%) (eSafety Commissioner 2017). Muslim children, as part of the cyber community and members of the Muslim community in Australia, repeatedly face Islamophobia as part of their everyday routine. In addition to witnessing cyber antiMuslim hate, hijabi girls continue their struggle with Islamophobia at Australian schools (Keddie et al. 2019).

Consequently, Muslim parents display significant concerns in choosing the right school for their children. For all Muslim parents, the right school is meant to be a setting ensuring the safety, comfort and confidence of their children (Jamal Al-deen 2019, p. 180). Yet Muslim parents' views on which school is right for their children varies.

\section{Schools and Parents Literature}

All parents have more or less similar expectations from schools, such as academic success, discipline and adherence to globally accepted moral values and social norms. In addition, parents expect to choose the best accessible, available and affordable school to make their daily life manageable (Cucchiara and Horvat 2014, p. 432). Eventually, school choice is a more sophisticated parental behaviour. According to Cucchiara and Horvat (2014, p. 490), school choice is like shopping, and it operates with the rules of a marketing industry. Accordingly, school shopping is a personal choice and includes inherently social and cultural processes, thereby affiliating or differentiating oneself from the other school choosers (Cucchiara and Horvat 2014, p. 275). As emotional and social beings, parents shape a "brand community" by school choice (Cucchiara and Horvat 2014, p. 491).

Moreover, the emerging research highlights that parental school choice, especially among the educated middle-class parents with fewer children, is more than a matter of 
manageability (Cucchiara and Horvat 2014, p. 489). Parents seek compatible parental and school mindsets (Jamal Al-deen 2019, p. 163), and further, some parents consider school choice a highly political and symbolic act (Reay et al. 2011). Cucchiara and Horvat (2014) research on white middle-class American families discloses that parental school choice is "a means of expressing and enacting a particular identity" about who they are and how they want their children to be (p. 487). By school choice, parents show their stance about broader issues such as race and class segregation, political engagement and urbanism (Cucchiara and Horvat 2014, p. 488). Such political discussions have more weight for middle-class educated families, who are on the other side of the fence as immigrants and members of racially and religiously targeted minorities in the cultural West.

The literature did not raise any connection between Muslim parents' school choice and parenting style. In fact, parenting style is closely associated with parental attitudes towards schooling. Parents' socio-economic class is found to be a key factor in shaping the 'cultural logics of childrearing' (Lareau 2002, p. 772), and no sheer difference is between the Black and White middle-class parents in making a deliberate school choice and involving their children with extracurricular activities since both groups could afford discretionary spending on their children's social enrichment (Lareau 2002). Although race seems to be a minor dimension in parental attitude, Vincent et al. (2013) study on middle-class Black parents disclose that experiences of racism bring an additional motivation to Black parents' childbearing experiences. They strive against the effects of racial inequality in both the education system and the labour market by instilling their children with good quality education, valuable life skills and cultural resources (Vincent et al. 2013). Concerted cultivation is also seen as a "potential defence" (Vincent et al. 2013, p. 435) against being marginalised and stereotyped as less capable or deserving than their White peers. While arming their children against racism, Black parents also introduce their children to incommunity activities and environments to strengthen their children's sense of self-esteem and pride (Vincent et al. 2013).

Concerted cultivation, which is not only a classed but also a racialised parenting strategy according to Vincent et al. (2013), is similarly observed among the middle-class parents in the cultural West. They are similarly motivated to curb the impact of discrimination, foster Muslim identity and provide good quality academic education for their children to involve them in the middle class. Like in the case of middle-class Black parents (Vincent et al. 2013), middle-class Muslim parents in the cultural West were not usually born into the middle class but strived for a considerable social mobility while facing racism and discrimination.

Educated middle-class Muslim parents in the cultural West go through similar processes in school choice. Both quantitative and qualitative studies in the literature disclose more or less similar parental reasons for choosing public or Islamic schools. While most Muslim parents prioritise religious and cultural values in their decision making, they also recognise the racist and secular challenges infused in the education system and school environment (Jamal Al-deen 2019, p. 164). Soliman (2016) explanation of five major themes in parental school choice include Muslim identity, social environment, school climate, academic education and other factors. Parental concerns about schools included the risk of diminishing self-esteem due to Islamophobia and discrimination (Sirin and Fine 2007) and violent extremism and social cohesion programs implying that Islam/Muslims are a source of conflict (Keddie et al. 2019), a highly secular environment pushing religion to a private sphere (Keddie et al. 2019), cultural and religious illiteracy about Islam, lack of dress codes and modesty (Ahmad and Szpara 2003), missing moral discipline (Merry 2005), Euro-centric curriculum (Khalifa and Gooden 2010) and the low quality in education (Merry 2005). Some Muslim students in public schools expressed lack of any high expectation from Muslim students which resulted in receiving inadequate support and motivation by teachers and counsellors (Ghazala 2013; Zine 2001). Not only children but also parents disclosed poor relationships with public schools (Clyne 2001) since the school admins seem to be "ill-prepared to meet the needs of Muslim students" (McAndrew 2010). 
Parents seeking cultural and religious conformity and consistency along with the home values, practice and pedagogy preferred Islamic schools (Ghazala 2013).

Ghazala (2013) grouping of Canadian Muslim parents in three groups according to their school choice and the reasoning resonates with the common parental tendencies disclosed in the literature. Those parents sending their children to Islamic schools instead of public schools expressed three main reasons: (a) school environment, (b) school language and (c) subject content and its pedagogy. Those preferring public schools made the decision (a) based on their own public-school experiences as children and (b) their religious and cultural beliefs. Those switching from public to Islamic schools did so due to (a) the lack of religious support and recognition and (b) unapproved social conduct, communication barriers, and curriculum in public schools.

Nevertheless, this article argues that the school choice formula for middle-class Muslim parents is not that simple. Despite experiencing similar challenges, the interviews with Muslim parents disclose parenting style as a pattern and strong stimulator in school choice.

There are four main types of parenting models: authoritative, authoritarian, permissive and rejecting. Authoritarian parents demand obedience and prefer their interests and expectations over the children's. In contrast, permissive parents show lenience in disciplining children, set no age-appropriate expectations and centralise children's interests. Rejecting parents (aka neglectful) are neither demanding nor responsive; they avoid parental responsibility by foregoing any structure. Authoritative parents provide emotional support, set high standards and grant children autonomy through clear and bidirectional communication (Darling and Steinberg 1993, p. 487). They equip children with "instrumental competence" to mediate individual and social needs and responsibilities (Husain 2013, p. 165). This type of parenting is common among faith-inspired parents. Such parents protect their children from risk behaviours (Husain 2013, p. 165), prefer love-orientation discipline and train their children to be empathetic to others (Husain 2013, pp. 166-7; Baumrind 1991). Husain (2013) recognises these parenting traits are derived from Christian and Jewish faith communities living in individualistic Western societies and may not reflect the parenting practices of ethnically and religiously different faith-inspired parents and their community-oriented practices in the cultural West. While revealing some associations between school choices and parenting style, this study explores nuanced approaches to parenting styles among the faith-inspired Muslim community in Australia.

\section{Methodology}

Focus group discussions and semi-structured interviews were conducted with Australian Muslim parents with the consent to use de-identified data for analysis and publication purposes, which was obtained in accordance with Charles Sturt University ethics protocols (Protocol: H19197) and the University of Western Australia ethics protocols (Protocol: RA/4/1/1651). The participants were predominantly mothers to explore children's experiences of Islamophobia and parental reflections. Although school choice was not a central theme in the interviews, the frequent reference to parents' reasoning for their school choice and reflections on their children's current schools shaped the basis of this article. Because the pilot study was aiming to explore Muslim mothers' and children's experiences with Islamophobia, nonprobability sampling (including convenience, snowball and purposive sampling) was used to recruit participants. Muslim mothers who experienced an Islamophobia incident and reported to the Islamophobia Register Australia and Muslim women from mosque communities and Islamic organisations in Muslim-populated suburbs in Sydney were invited to the study. Facebook and email campaigns also helped reach the broader Muslim community in Australia. For this paper's scope, only those participants addressing parental school choices in their interviews were included in this article.

\section{Participant Demographics}

Twenty-nine interviews and three focus group discussions (FGD) $(N=23)$ were conducted by the author in Sydney as part of a large interstate study in New South Wales, 
Western Australia and Victoria. ${ }^{1}$ Sixteen interview participants (out of 29) and eight FGD participants (out of 23) were included in this article because they reflected on parental school choice, their children's as well as their own schooling experiences in Australia.

Among the selected participants for this article, only two were men. Mothers' involvement in the interviews and FGD was prioritised in the recruitment since mothers spend more time with their children and are perceived as the main caregivers both culturally and religiously. All of them, except one, were parents. Despite having no children, her input on her own childhood and school experiences was found relevant to include in this article. All the participants except two were from Sydney. Those participants from Adelaide (South Australia) and Dubbo (New South Wales) were interviewed remotely via Zoom. The demographics of interview and FGD participants are detailed in Tables 1-3.

Table 1. Demographics of Interview Participants.

\begin{tabular}{|c|c|c|c|c|c|c|}
\hline No & Name & Interview Date & Age Range & Education/Occupation & Ethnic Background & Schooling in AU \\
\hline 1 & Bushra & $24 / 05 / 2018$ & $30-39$ & $\begin{array}{l}\text { Tertiary edu/case } \\
\text { manager }\end{array}$ & Syrian-Bosnian & Yes \\
\hline 2 & Mustafa & $05 / 12 / 2017$ & $40-49$ & $\begin{array}{c}\text { Primary school } \\
\text { teacher }\end{array}$ & Lebanese & Yes \\
\hline 3 & Alia & $07 / 12 / 2017$ & $30-39$ & $\begin{array}{c}\text { Tertiary } \\
\text { edu/community } \\
\text { volunteer }\end{array}$ & Egyptian/Australia & Yes \\
\hline 4 & Farida & $08 / 12 / 2017$ & $30-39$ & Homemaker & $\begin{array}{c}\text { Somalian but born in } \\
\text { UAE }\end{array}$ & Yes \\
\hline 5 & Firdaus & $10 / 12 / 2017$ & $30-39$ & $\begin{array}{c}\text { Tertiary } \\
\text { edu/scripture } \\
\text { teacher }\end{array}$ & Lebanese & Yes \\
\hline 6 & Asma & $10 / 12 / 2017$ & $40-49$ & Homemaker & Australian & Yes \\
\hline 7 & Razia & $10 / 12 / 2017$ & $40-49$ & Tertiary edu & Bangladeshi & No \\
\hline 8 & Noura & $12 / 12 / 2017$ & $40-49$ & Childcare own home & Bangladeshi & No/TAFE in AU \\
\hline 9 & Farkhunda & $18 / 12 / 2017$ & $50-59$ & $\begin{array}{l}\text { Community } \\
\text { volunteer }\end{array}$ & Lebanese & Yes \\
\hline 10 & Helena & $20 / 12 / 2017$ & $30-39$ & $\begin{array}{c}\text { Teacher aide/BA } \\
\text { student }\end{array}$ & Taiwanese & Yes \\
\hline 11 & Jinan & $06 / 04 / 2018$ & $30-39$ & $\begin{array}{l}\text { Teacher and higher } \\
\text { degree student }\end{array}$ & Lebanese & Yes \\
\hline 12 & Sally & $30 / 05 / 2018$ & $40-49$ & $\begin{array}{c}\text { Global lens company } \\
\text { manager }\end{array}$ & Australian & Yes \\
\hline 13 & Jana & $13 / 07 / 2018$ & $20-29$ & Paralegal & Lebanese & Yes \\
\hline 14 & Farah & $01 / 08 / 2018$ & $40-49$ & TAFE teacher & Afghani & $\mathrm{PhD}$ in $\mathrm{AU}$ \\
\hline 15 & Olivia & $08 / 08 / 2018$ & $20-29$ & Medical researcher & Australian & Yes \\
\hline 16 & Zareer & $10 / 08 / 2018$ & $30-39$ & Software engineer & Indian & No \\
\hline
\end{tabular}

Table 2. Focus Group Discussions.

\begin{tabular}{cccc}
\hline Focus Group & Location & No. Participants & Included Participants \\
\hline FG-S-1 & $\begin{array}{c}\text { An Islamic } \\
\text { organisation }\end{array}$ & 7 & 3 \\
FG-S-2 & A school's campus & 13 & 3 \\
FG-S-3 & An Islamic & 3 & 2 \\
Total & organisation & 23 & 8 \\
\hline
\end{tabular}


Table 3. Demographics of Focus Group Discussion Participants.

\begin{tabular}{|c|c|c|c|c|c|c|}
\hline No. & Name & FGD Date & Age & Education/Occupation & Ethnic Background & Schooled in AU \\
\hline 1 & Farhana & $\begin{array}{c}\text { FGD-I } \\
12 / 11 / 2017\end{array}$ & $30-39$ & English Teacher & South African & Yes \\
\hline 2 & Sawsan & $\begin{array}{c}\text { FGD-I } \\
12 / 11 / 2017\end{array}$ & $40-49$ & Homemaker and BA student & Kurdish & Yes \\
\hline 3 & Jenny & $\begin{array}{c}\text { FGD-I } \\
12 / 11 / 2017\end{array}$ & $30-39$ & Homemaker & Australian & Yes \\
\hline 4 & Meliha & $\begin{array}{c}\text { FGD-II } \\
15 / 11 / 2017\end{array}$ & $50-59$ & High school Coordinator & Turkish & Yes \\
\hline 5 & Hayley & $\begin{array}{c}\text { FGD-II } \\
15 / 11 / 2017\end{array}$ & $50-59$ & Homemaker & Lebanese & Yes \\
\hline 6 & Rubiyah & $\begin{array}{c}\text { FGD-II } \\
15 / 11 / 2017\end{array}$ & $40-49$ & Homemaker & Lebanese & No \\
\hline 7 & Akila & $\begin{array}{c}\text { FGD-III } \\
18 / 11 / 2017\end{array}$ & $50-59$ & Childcare Aide & Egyptian & No/TAFE in AU \\
\hline 8 & Sibel & $\begin{array}{c}\text { FGD-III } \\
18 / 11 / 2017\end{array}$ & $30-39$ & Pharmacology & Turkish & Yes \\
\hline
\end{tabular}

All participants were self-identified religious middle-class parents, the majority of the mothers wore hijab and most participants were educated (tertiary education) and were second-generation Muslims. If not born in Australia, the majority (except two) arrived in Australia in their childhood. A few of the participants were converts to Islam, coming from an Anglo-Celtic background.

\section{Practical Convenience vs. Deliberate School Choice}

\subsection{Schools in Australia}

There are 10,000 schools in Australia; 25\% are non-governmental within which Catholic schools hold the largest portion. Schools belonging to the other ethnic and religious groups are growing the fastest in Australia (O'Donoghue 2000). School politics in Australia is neo-liberal and accommodates multiple parental expectations by providing families with sufficient variety (Jamal Al-deen 2019, p. 169).

Islamic schools in the cultural West were established as a result of parental dissatisfaction with the secular and inherently Christian public-school systems. They are designed to culturally and religiously accommodate Muslim children and prevent them from feeling alien (Molook 1990). Islamic schools propose to raise well-adjusted individuals by recognising their religious identity while fostering their religious values (Shakeel 2018, p. 393). Parents articulate similar reasons for choosing Islamic schooling, such as strengthening children's Muslim identity and belonging, preventing discrimination and school bullying and instilling children with Islamic knowledge and Islamic values education (McCreery et al. 2007). Nevertheless, Islamic schools are criticised and scrutinised by some circles for not reinforcing diversity and leading diversion from the dominant culture (Wolf 2018; Shakeel 2018, p. 393). Nevertheless, positive portrayal of Islamic schools appears to override such scepticism (Shakeel 2018, p. 393).

Apart from Islamic schools, there are nondenominational independent schools which have been founded and are administered by Muslims. These schools deliver education from kindergarten to Year 12 and operate in different states across Australia. Despite operating under different school names, all are connected to the Australian Universal Federation. These schools are mostly in Muslim-populated suburbs in Australia. Although they accept students from all religious backgrounds, these schools are chosen predominantly by Muslims. Non-conservative and non-religious Muslim parents prefer these schools over Islamic schools.

Home schooling is another avenue for parents who are dissatisfied with the available school variety and aim to reinforce home values along with the desired level of academic 
excellence (Jones 2012). This option is suitable for faith-inspired parents seeking to instil their children with the desired level of religious excellence.

Among all the available school options, public schools are the most common, efficient and affordable schooling type among middle- and lower-class Muslim families residing in Muslim-populated suburbs. The structural ruptures that lead minority communities to live in ghettos upsets the educational quality in public schools for Muslim-populated suburbs. The public schools in these disadvantaged suburbs are mostly populated by students with a language background other than English and are usually under-performing (Suliman and McInerney 2006; Ho 2019). Furthermore, these schools in immigrant-populated suburbs minimise the chance of mingling with the White Australian population while exposing Muslim children to ethno-religiously diverse other minority communities.

Although the neo-liberal schooling system in Australia provides sufficient variety for parents, structural ruptures and seeking "people like us" in schooling by White Australian and minority parents deepen the structural discrimination further (Ho 2019).

\subsection{Practical Convenience}

Although schooling choice reflects parents' salient identities (Cucchiara and Horvat 2014), some practical factors such as location and financial affordability are in force in decision making. Interviewed parents were largely from Muslim-populated suburbs where public schools with significant Muslim student populations, Islamic schools and Muslim-initiated non-denominational schools are equally available. Families residing in non-Muslim-populated Anglo suburbs looked for ethnically mixed neighbourhood schools, where Muslim children would feel less aligned within an ethno-religious variety. Whether by choice or lack of choice, parental reflections on their children's schools disclosed parental attitudes towards certain types of schools.

Most of the participants were middle-class families and none raised school fees in relation to their school choice. Governmental support for school fees makes Islamic and non-denominational schools affordable for many parents in Australia. Nevertheless, school fees may be a deterrent for some parents due to simultaneously schooling multiple children. Likewise, some participants who were either homemakers or still in tertiary or higher education might have found Islamic or private schools unaffordable. Financial unaffordability remains an unarticulated factor in the interviews. Likewise, some parents did not openly confirm the practicality of home schooling while sending their children to Qur'an memorisation schools during weekdays. In addition to location, financial and practical convenience, some changes in life circumstances were influential in making practical manoeuvres in parental school choice. For instance, upon the increasing number of school age children in the family, Helena had to move her eldest daughter from an Islamic school to a nearby public school; upon divorcing from her husband, Farkhunda had to transfer her two sons from Islamic to a public school while keeping her daughter in the same Islamic school; and upon moving from a Muslim-scarce suburb to a Muslim-populated suburb, Farida faced more schooling options and chose a nearby non-denominational private school for her children.

\subsection{Deliberate School Choice for Boys and Girls}

Some parents made informed decisions for the discipline, comfort and academic success of girls and boys. While choosing a high school in later years and especially for their daughters, who were either wearing or considering wearing a hijab as young women, parents intentionally sought single-sex schools. The same sensitivity was not expressed for the teenage boys in the same family. Noura and Jinan sent their sons to co-educational public schools while sending their daughters to girls' high schools. When Noura's husband considered sending her daughter to the same school with his son, Noura objected saying "I do not want her to go to where boys are. Also, my son does not want, I do not want her to go to that school. He [her son] understands mixing boys and girls is not good" (Noura, 
interview, 12 December 2017). Providing Muslim (mostly hijabi) girls a comfortable high school environment was repeatedly mentioned by most of the parents.

Some parents prioritising discipline and academic success, especially in high school years, considered switching from public to private schools in later school years.

... [W] hen you go to a public school, you think yeah I'm going for the sake of going. Parents, some parents don't care ... They're [children] going there [public school] for the sake of their friends, hanging out, when you're at a private school your parents are investing and you do see a difference in the child, you do see the child has more of an interest in learning and is more disciplined. (Firdaus, interview, 10 December 2017)

Within the available diverse schooling options, there is a broad spectrum of schooling experiences ranging from absolute isolation to assimilation. While isolation is a risk in highly homogenous schooling settings where children are not exposed to different cultures or religions, assimilation is similarly a risk in some school settings where Muslim presence is almost non-existent and Muslim children are uncomfortable in disclosing their Muslim identity. Within these two extremes, which were present only in a few cases, the majority of the school settings provide Muslim children with ethno-religiously familiar surroundings. All participants mentioned Islamophobia as an instrumental factor in their school choice. Yet, parental attitude in school choice was diverse and based on: (1) parents' own schooling experiences in childhood in the Australian schooling system; (2) participants' parenting styles, which shaped parental attitude in upbringing their children in the Australian context and influenced their school choice; and (3) custom-made parenting, which is shaped by some children's personalities demanding a particular school type.

\section{Parental Childhood Experiences}

The participants' median age was 30-40 years. Those parents schooled in Australia were the children of immigrant parents who were foreign to the Australian schooling system and mindset and unable to support their children's schooling. Although most parents coming from developing countries highly valued education, their unfamiliarity with the Australian schooling system made them helpless for their children's education. The participants who were schooled in Australia were in primary school in the 1990s, when the Gulf War was in force, Bosnia was at war with Serbia and the Clash of Civilisations theory by Samuel Huntington was widely accepted and circulated in academia and political circles. The events of $9 / 11$ only heightened anti-Muslim sentiments. Shortly after $9 / 11$, the Cronulla riots showcased the rising tension towards Muslims in Australia. The participant parents were in high school when this global and local antipathy against Muslims was in force. Although their primary school experiences were mostly about being vulnerable immigrant children in a foreign culture, their high school experiences during adolescent years were influenced by global and local animosity directed at Muslims.

Second-generation parents experienced different schooling experiences, such as assimilation (e.g., eating Devon (pork) at lunch time in the absence of parental guidance for halal options in Sibel's case), lack of a vision and role models for academic success as members of a disadvantaged minority at an Anglo-dominated school (as was the case of Jinan), being bullied by their Anglo peers as a brown, immigrant child with poor language skills and parental support in a homogenous primary school setting (as was the case of Mustafa), or being respected and valued as a member of the Australian multicultural society (as was the case of Bushra).

Such childhood experiences shaped parents' perception of school types and influenced their school choice for their children. For instance, Sibel, enjoying her childhood years in absolute ignorance of her Muslim identity, sent her kids to a non-Muslim-dominated public school close to her work, but unlike her parents, she taught her children what is halal and what is not. Yet, to fully immerse her little daughter in her surroundings, Sibel deliberately kept such information minimal. Accordingly, Sibel's daughter thinks every hijabi woman is Turkish because her hijabi grandmother is Turkish. 
Jinan sent her kids to nearby public schools, but as an educator, she was closely involved in her children's schooling journey. Going to an Anglo-dominated school and feeling the sense of difference, which she mediated by mingling with a handful of ethnically different girls like herself, Jinan realised the harm of homogeneity, whether it be Anglo or Muslim. Hence, Jinan deliberately chose to send her children to ethno-religiously mixed public schools rather than the Muslim-populated nearby public school.

The harm of one dominant race can lead to heavy racism when coupled with ignorance. That is what Mustafa experienced in his childhood:

We were actually exposed to a lot of racism. The school I went to was mostly Anglo-speaking school ... and I think that set the foundation or set my attitude for the rest of my life in a way. Since being exposed to a lot of the racism, um, I've become more defensive, in a way more aggressive, um, I'm usually a very ... how can I explain this. I'm not an aggressive person, but normally I'm very edgy and very alert ... And because it was something I was exposed to as a young kid constantly, I'm always on alert. Even till now. Around certain groups ... I can no longer go to a particular area and feel totally at ease. I'm always like, watchful, mindful. (Mustafa, interview, 5 December 2017)

Despite being a teacher in an ethno-religiously diverse public school, Mustafa could not get rid of this protectiveness, which influenced his parental mindset and school choice:

It made me extremely protective and it made me very conscious of my decisions. I consciously make sure that my kids are always around people who look like them, speak a similar language, or people who will make them feel comfortable, and part of the group. I don't wanna expose my kids to what I went through. I don't think they could probably handle what we could handle as kids because, maybe because we had a tougher upbringing. But the psychological impact was to me was very big. So, like I said, I've consciously made those decisions to move them away. (Mustafa, interview, 5 December 2017)

Mustafa's overprotective approach led him to send his children to an Islamic school, where children also felt comfortable and preferred to be, according to him.

Unwanted public-school experiences in childhood aroused fears in parents for their own children. For instance, Sawsan, who felt ashamed of her mother's "conservative clothing" and did not want to be seen with her at school, feared that her children would feel the same if they went to a public school. To avoid this, Sawsan decided to send her children to a Muslim-populated private school where being Muslim and wearing hijab are accommodated and appreciated.

They won't tell you that they don't want you to come, but they'll be, like, "Mum, do you have to come? Can't you ... ?" But, indirectly, they try to say 'you're wearing the scarf. If you come with me ... ' because image is everything to a teenager, that's what's important to them, and it's like 'you're spoiling my image'. Yeah. I used to feel that way about my mum, though I used to get embarrassed when mum would come. I used to feel that way. But, because, as I said, I was the minority, whereas now my children in private schools, they beg me to go ... and I'm, like, "Oh, I love that they love me to be there". I love that they love having me around-but I was never like that. (Sawsan, FGD, 12 November 2017)

In contrast to Mustafa and Sawsan's childhood experiences, Bushra found her Muslim identity grew stronger in the welcoming atmosphere of her Anglo-dominated public school. Bushra felt she was treated with respect as a worthy member in the school community. This positive experience reinforced Bushra's sense of belonging as she repeatedly emphasised that she is an Australian. Furthermore, her positive school experience reinforced the idea that education is the sole solution to racism and uneducated people are racist. Bushra chose to send her children to a public school where they would be exposed to multicultural Australian society. 
Some parents like Firdaus went to a Muslim-populated school in her suburb, did not see any harm of it and sent her children to a similar public school. Different from her parents, she adopted a more hands-on approach by getting involved in her children's school community.

\section{Parental Mentality and Parenting Method Shaping the School Choice}

Parental school choice is not independent from parents' earlier school experiences, which was very well self-analysed by Mustafa, who associated his overprotective approach with his childhood racism experiences at school. In addition, the research also confirmed that school choice reflects parental mentality, especially among the middle-class White members of society in the Western world (Cucchiara and Horvat 2014), including Australia (Cahill 2009, p. 61). Like their Western counterparts, our participants, as educated middleclass Muslim parents with a small number of children, took the responsibility of making deliberate decisions about their children's schools. Table 4 summarises our participants' approach to school types as a reflection of their parenting style.

Table 4. Manifestation of Parenting Styles in Schooling.

\begin{tabular}{|c|c|c|}
\hline Parenting Styles & Description & Manifestation in Schooling \\
\hline Authoritarian Parenting & $\begin{array}{l}\text { Demand obedience and tend } \\
\text { to control their children } \\
\text { according to their values and } \\
\text { own priories. }\end{array}$ & $\begin{array}{l}\text { Seek a schooling environment } \\
\text { that completely overlaps with } \\
\text { home values and priorities. } \\
\text { Feel threatened to immerse } \\
\text { their children into } \\
\text { uncontrollable environments. }\end{array}$ \\
\hline Permissive Parenting & $\begin{array}{l}\text { Show lenience in disciplining } \\
\text { children, set no } \\
\text { age-appropriate expectations. }\end{array}$ & $\begin{array}{l}\text { Immerse their children into a } \\
\text { completely foreign school } \\
\text { environment. Want their } \\
\text { children to be immersed in the } \\
\text { dominant culture. }\end{array}$ \\
\hline $\begin{array}{c}\text { Rejecting (aka Neglectful) } \\
\text { Parenting }\end{array}$ & $\begin{array}{l}\text { Neither demanding nor } \\
\text { responsive, avoid parental } \\
\text { responsibility by foregoing } \\
\text { any structure. }\end{array}$ & $\begin{array}{l}\text { These types of parents were } \\
\text { absent in the participants. }\end{array}$ \\
\hline Custom-made Parenting & $\begin{array}{l}\text { Put aside their own } \\
\text { expectations as parents and } \\
\text { prioritise children's needs and } \\
\text { demands. }\end{array}$ & $\begin{array}{c}\text { Seek a school match according } \\
\text { to their children's interests, } \\
\text { needs, talents and/or } \\
\text { personality. }\end{array}$ \\
\hline Authoritative & $\begin{array}{l}\text { Provide emotional support, } \\
\text { set high standards and grant } \\
\text { children autonomy through } \\
\text { clear and bidirectional } \\
\text { communication. } \\
\text { Protect their children from } \\
\text { risk behaviours (Husain 2013, } \\
\text { p. 165), adopt love and } \\
\text { empathy-oriented } \\
\text { disciplining. }\end{array}$ & $\begin{array}{l}\text { Show varying levels of } \\
\text { tolerance in exposing their } \\
\text { children to the other people } \\
\text { and alternative teachings, } \\
\text { philosophies, religions and } \\
\text { cultures in the school } \\
\text { environment. }\end{array}$ \\
\hline
\end{tabular}

Middle-class Muslim parents made school choices based on their parental views on the boundaries of religious education, in which ways children's identity should be nurtured, to what extent children should adapt to their social environment and what would be compromising or confronting for Muslim children under a secular and inherently Christian schooling system and socio-politically Islamophobic climate.

As addressed in the literature, faith-inspired parents in the cultural West tend to be authoritative. Yet the level and context of an authoritative approach varies, especially in 
the schooling context. No signs of rejecting (neglectful) parenting were observed, whereas permissive parenting was in force in a few cases. Being lenient, the permissive parenting style favours heterogeneous environments to immerse their children into significantly new and diverse environments, which required going out of one's comfort zone and taking risks. As rightly put by Hussain, authoritative parenting turns into authoritarian parenting among those insisting on dogma or one particular interpretation and performance of the religion (Husain 2013, p. 168). Authoritarian parents seek homogenous school environments for their children and tend to give clear instructions and consistent messages, thereby controlling their children's circumstances including their religious, academic and social environments. Sometimes the child's characteristics, needs and demands made the parents cognisant of adopting custom-made parenting. Such parents follow signs from their children in school choice.

\subsection{Authoritarian Parenting in Schooling}

The degrees and types of authoritarian parenting may vary according to context. The authoritarian parenting within the scope of this paper, however, is limited by the level of parental tolerance in exposing their children to other people and alternative teachings, philosophies, religions and cultures in the school environment.

Those participants who are fond of instilling their children only with the home version of religious interpretation found the diversity even within the relatively homogenous Islamic schools challenging. Finding her daughter confused between home and school culture and religious criteria, Asma decided to withdraw her daughter from her Islamic school and started home schooling:

The eldest we did send her to a private Islamic school but we found that that was like contradicting itself really because we were teaching at home some values and the school was teaching different values and our daughter couldn't reconcile that. That well these are Muslims too and they're telling us that this is okay and you're saying it's not. (Asma, interview, 10 December 2017)

Exposure to diverse opinions, religions and cultural practices were perceived as a source of dispute for authoritarian parents. Razia started home schooling to save her son from confusion:

I can't imagine that my son will go to the [public school], that he will be taught by a teacher that I don't know what his or her belief is, I don't want. Because I heard from my friends whose children used to go to public school, when Christmas time comes, they want to get a Christmas tree at home. So, it's really scary, because they will learn something at school and we are trying to teach them something totally different, it's totally different. So, then children become confused ... Yeah, because I know that nowadays most of the people are atheist, so I don't want my children to get those ideas, because children use most of their time at school, eight hours, nine hours, so I don't know what is going on there. (Mustafa, interview, 10 December 2017)

Razia's concerns resonate with the criticism of public schools, whose foundations are shaped by "secularity and Christian privilege" (Keddie et al. 2019) and whose cultural and religious inclusion efforts stayed at a "superficial" level (Keddie et al. 2019). Razia, as a first-generation immigrant in Australia, also echoes the fear for a foreign school system, which is commonly observed among new immigrant families feeling outlandish, especially under an Islamophobic climate (Keddie et al. 2019). As a first-generation Muslim parent, who is relatively new to the Australian society and its schooling system, Zareer shares similar sentiments with Razia about public schools, which are based on peer feedback rather than personal observations (Jamal Al-deen 2019).

While the diversity of religious views within the same religious community became a source of discomfort for Asma, the ethnic diversity within the same community became an issue for Razia when she discovered her son was bullied due to his skin colour by his 
co-religionists. Despite an easy resolution by contacting the school administration, both parents opted for silently switching to home schooling. Although they did not make any negative comments about the school administration, Martinez (2009) states that home schooling was chosen by some Muslim parents who do not see much difference between Islamic and public schools.

Overprotective parents controlling their children's school environment through home schooling did not want to withdraw their children from society but aimed to strengthen their children's Muslim identity by taking preventive measures against unwanted incidents. Recognising the impossibility of controlling others' behaviours, Razia decided to invest in shaping her son's behaviours by cultivating a strong Muslim identity and teaching him how to confidently cope with others' unwanted behaviours. Razia believes this is achievable through home schooling:

I want to have them brought up with a very strong mentality, as a very strong person with a strong mentality so they can cope with the environment and I can pray. That's all, that's all I can do. Because I can't control others, I can't control others and we have to decide what we want to do whether we want to follow our deen or not. (Razia, interview, 10 December 2017)

Following the same authoritarian approach, some parents expressed their regret for sending their children to a public school, where the children were beyond parental control. Noura desired an Islamic school fully in charge of controlling her children's behaviours and strengthening their Muslim identity. Noura warned her son to not "talk and look at the girls" without giving any explanation but hoping "when he goes to university, he will understand" (interview, 11 December 2017). In turn, her instructions and advice at home were taken lightly by her children. Her daughter and son go to different public high schools, which challenged Noura by bringing bad examples of Muslims from their schools. They argue a strong Muslim identity would not make one a good person. Noura expressed her concerns for her son, who hides his Muslim identity at school and constantly criticises Muslims. He eventually started criticising Noura's hijab and expressing his preference for her pre-hijabi clothing. Noura wanting to control his son closely had actually distanced him while he is at school. She was not even sure if her son was fasting at school during Ramadan. Noura associated all these undesired changes in her son with not sending him to an Islamic school:

... [N]ow I am regretting I should have put him in Muslim school, so he would not have friends like that ... Because in an Islamic school, if they have praying time they will also pray, so he will learn things, they will teach him things. In here I can teach him online. (Noura, interview, 12 December 2017)

Criticising Muslims, disliking a mother's hijab and shying away from Muslim identity are signs of assimilation for Muslim children like Noura's son. Noura's authoritarian parenting (such as giving commands without explanation) is likely to cause negative reactions and rejection by her teenage son.

\subsection{Authoritative Parenting}

Authoritative parents protect their children from risk behaviour (Husain 2013, p. 165) by putting them into controllable diversity and prioritising their comfort by providing a safe and secure school environment. As explained in Table 5, the level of autonomy granted to children varies in this spectrum. 
Table 5. The Range of Authoritative Parenting and Their Manifestation in Schooling.

\begin{tabular}{|c|c|c|c|}
\hline \multicolumn{2}{|c|}{ Parenting Style } & Description & $\begin{array}{l}\text { Manifestation in } \\
\text { Schooling }\end{array}$ \\
\hline \multirow{3}{*}{ Authoritative } & $\begin{array}{l}\text { Lower end of the } \\
\text { Spectrum }\end{array}$ & $\begin{array}{l}\text { Desire a school } \\
\text { environment that } \\
\text { accommodates } \\
\text { faith-inspired parents' } \\
\text { ethical, cultural and } \\
\text { religious needs and } \\
\text { priorities (Shakeel 2018). }\end{array}$ & $\begin{array}{c}\text { Opt for religiously } \\
\text { homogenous schools. }\end{array}$ \\
\hline & Moderate & $\begin{array}{l}\text { Negotiate their school } \\
\text { priorities with the need } \\
\text { for their children's } \\
\text { comfort and happiness } \\
\text { for a healthy sense of } \\
\text { belonging. }\end{array}$ & $\begin{array}{l}\text { Value developing a } \\
\text { Muslim identity in an } \\
\text { ethno-religiously } \\
\text { diverse public-school } \\
\text { setting. }\end{array}$ \\
\hline & $\begin{array}{l}\text { Upper end of the } \\
\text { Spectrum }\end{array}$ & $\begin{array}{l}\text { Exceed moderate } \\
\text { authoritative attitude and } \\
\text { become closer to } \\
\text { permissive parenting by } \\
\text { exposing their children to } \\
\text { a wider variety but } \\
\text { without losing parental } \\
\text { control of their children's } \\
\text { religious identity (Bright } \\
\text { Horizons Education } \\
\text { Team 2020). }\end{array}$ & $\begin{array}{c}\text { Avoid pure } \\
\text { Anglo-Saxon } \\
\text { dominance by } \\
\text { choosing ethnically } \\
\text { mixed public schools } \\
\text { in the absence of } \\
\text { Muslims at school. }\end{array}$ \\
\hline
\end{tabular}

\subsubsection{Authoritative Parenting-Lower End of the Spectrum}

Most of the parents "across the Western world are risk-averse" as they choose schooling that they are used to (Cahill 2009, p. 221). Likewise, Muslim parents, most of whom were schooled in Australia as children of new immigrants while grappling between inhouse and outside (school) culture, similarly displayed risk-averse tendencies while choosing their children's schools under an Islamophobic environment.

The lower end of the spectrum in authoritative parenting consists of parents who desire a school environment that accommodates faith-inspired parents' ethical, cultural and religious needs and priorities (Shakeel 2018). While Western parents who are more fixed in their conservatism tend to choose Catholic schools (Cahill 2009, p. 211), Muslim parents who are more fixed in their conservatism opt for religiously homogenous Islamic schools. Such parents are cognisant of the amount of school time and its impact on children. For instance, Zareer emphasises the significance of school type and environment, where children spend most of the day:

Seven/eight hours a day, these guys will be spending a major part of their day with their friends. So, their major part of the day should actually be with the right people, right friends, people who are studying the same ethics and values that we actually tend to nourish or cherish. That's one major reason, plus I've heard stories about-I wouldn't say racism, but education system for the public sector is not much up to par with private education. (Zareer, interview, 10 August 2018)

In addition to ensuring children are with the "right people", some parents perceive the religiously homogenous school environment as a "safe zone". According to Mustafa, when children "have more in common" with the rest of the school they feel like it is "where ... they belong". Having Muslim teachers, fasting together during Ramadan, starting the day with a communal prayer and performing congregational ritual prayers during the day are mentioned as contributing to what makes a common school culture for every student (interview, 5 December 2017). 
According to Mustafa, Islamic schools provide healthy identity development for his children who are "more comfortable", "happier" and "at ease" by "being around people who look like them and speak the same language with them" (interview, 5 December 2017). This sentiment resonates with the literature underlining that Islamic schools' routine fosters a sense of Muslim identity (Driessen and Valkenberg 2000). Mustafa, like many other parents in the cultural West (Shah 2012), thinks his children are protected from racism in an Islamic school.

In contrast, some parents view Islamic schools as easy targets for Islamophobes and expressed anxiety for sending their children to Islamic schools: "My kids were at an Islamic school" (Jenny, FGD, 12 November 2017). Jenny is so scared of an anti-Muslim attack on an Islamic school that she does not dare articulate the rest of the picture in her mind. Some parents like Sawsan avoid this type of fear by sending their children to non-denominational Muslim-administered and populated private schools (Sawsan, FGD, 12 November 2017).

Observing the damaging impact of discrimination in public schools and acknowledging the stigmatisation of Islamic schools, Akila decided to send her children to a non-denominational Muslim-administered private schools. Akila made her school decision while working at a state childcare centre, where she realised a growing sense of difference among pre-school Muslim children who were removed from the rest of the children to be given a different type of food that is religiously compliant (halal). Akila thought her children would feel neither completely different from the rest of the school nor completely isolated from the rest of the society in a non-denominational private school (FGD, 18 November 2017).

\subsubsection{Moderately Authoritative Parenting}

Those participants who are at unease with religious enforcement in Islamic schools prefer a slightly similar version: Muslim-administered non-denominational private schools that instil value education without enforcing Islamic rules.

Those sending their children to public schools for financial or other reasons faced two options: send their children to Muslim-populated schools or schools where Muslims are a significant minority (up to $40 \%$ ). Most of the parents expressed their satisfaction with Muslim-dominated public schools. These parents valued developing a Muslim identity in an ethno-religiously diverse public-school setting. Moderately authoritarian parents justified their school choice with the need for their children's comfort and happiness to develop a healthy sense of belonging by connecting with the peers from the same ethnic and religious background while schooling in moderately mixed ethno-religious diversity.

According to Jinan, children in Muslim-populated public schools "always felt secure because they've got a community behind them, like their peers and their friends. They haven't felt isolated. They haven't felt different". The shared ethno-religious background was valuable, especially for refugee students who are about to adapt their new school environment (interview, 6 April 2018). According to Jinan, the presence of Muslim teachers in the school was a source of comfort for refugee children.

I think there are two Muslim teachers all up and the kids really respond well to them, particularly the refugee students. They rely on them for support and for guidance ... I think once the Muslim parents see a Muslim lady that's in a position of authority within the school, they like to talk to her. People like to talk to people that are the same as them. They like that element of commonality. (Jinan, interview, 6 April 2018)

Surprisingly, Farkhunda echoed similar sentiments for her third-generation grandson, who was "fascinated" to see a Muslim teacher in his school, who gave him a sticker for learning the Qur'an outside school. Similarly, Sibel realised her daughter, who is also third generation, was excited to see a hijabi teacher in her primary school one day. Such excitement, according to Farkhunda, indicated a human need for everyone from all generations: "Everyone wants to belong to someone or something, like a group" (interview, 18 December 2017). 
Muslim-populated schools are a good match for hijabi girls. Firdaus admitted her daughter does not have any difficulty with wearing the hijab in her school because of the "open-minded" and "accepting" school administration (interview, 10 December 2017). All the parents showing authoritative parenting in their schooling choice indicated with anecdotes that public schools in Muslim-populated suburbs can supply Muslim children's needs to some extent.

Empathy and Love-Oriented Discipline by Faith-Inspired Authoritative Parents

Husain notes that faith-inspired authoritative parents disclose two distinct attributes while instilling their children with a religious identity: induction by building empathy and love-oriented disciplining (Husain 2013). While some authoritarian parents like Noura find a religious setting in Islamic schools instrumental to following religious rituals and adopting a religious identity, authoritative parents want their children to be religious by instilling them with love-oriented discipline.

Some faith-inspired authoritative parents value free-will and rational decision making by their children. Some parents criticise parental control over children's educational environment through home schooling and a uniform religious culture in Islamic school settings. They also argue that children can develop a stronger religious identity by choice in a school environment where there is no religious enforcement.

Rubiyah, a mother not wearing a hijab, expressed her concerns for her children starting to be judgemental about others, upon which she withdrew her children from an Islamic school. The lack of understanding she faced in the Muslim community for not wearing the scarf made the mother project her concerns onto Islamic schools (FGD, 17 November 2017).

Likewise, expressing her earlier school years in an Islamic environment as being "in a bubble", Jana interpreted a mixed public-school environment, where "everyone was really multicultural and nice", instrumental in nurturing empathy and avoiding judgemental generalisations (FGD, 13 July 2018). Diversity also enabled Jinan to teach her children about avoiding generalisations:

I kind of teach them that we treat everyone equally, everyone is the same, everyone has got their beliefs, we've got our beliefs, and even for the Muslims that they have, as bad examples of Muslims, I just say, "We're not like that, we don't do that". (Jinan, interview, 6 May 2018)

Apart from developing empathy, disciplining by love rather than law is repeated by some parents, who send their children to other than Islamic schools. Rubiyah, the non-hijabi mother, appraised her children's religious practices such as fasting in Ramadan and praying daily by calling it "real Islam". According to her, children's religious practices should happen by choice and out of love rather than by force and out of fear (FGD, 15 November 2017).

Helena also uses the term religion by love rather than law when explaining her daughter's connection to hijab. Helena's daughter initially started wearing the scarf as part of her uniform at her Islamic school but became accustomed to it and continued wearing it even after moving to a public school where she was the only hijabi girl. When Helena reminded her daughter that she does not need to wear the scarf anymore, her daughter insisted on wearing it by expressing her love for the hijab. Helena compares her daughter's earlier complaints about the hijab in the Islamic school with her insistence on wearing it after going to the public school: "She couldn't feel the love for it, but now that she has an option, if she had to make a choice, she wants to wear it" (interview, 20 December 2017).

Like Helena, Jinan observed her son is protective of his religion in a religiously mixed public-school environment. Jinan interprets preservation of her son's religious identity and confidence in his Muslim identity with being provided with a choice:

I remember once he was invited to a principal's morning tea and it happened to be Ramadan and he said to me, "I don't want to go because I'm fasting". I said, "Well, you have the choice. You cannot fast and you can go and participate or you can go and participate and tell them you're fasting". I don't like to tell the 
child what to do. I like to give them options. I was raised from a perspective of right and wrong, black and white, and I think this is very dangerous. This is not a very good thing. If you want to do that, you need to give the child an explanation why. But, in saying that, you still need to give them choice. The child has to be able to comprehend a decision and be satisfied with the decision that he's made. (Jinan, interview, 6 April 2018)

According to Jinan, children in such settings become "very protective of their fasting and Ramadan. They hold that up in very high esteem". For Jinan, raising children with informed choices by providing them with options is essential to prepare them according to the demand and realities of their own age, which "is so open; social media, internet, fake news, propaganda" and where "they need to be able to decipher between right and wrong, morally correct, what's incorrect. They need to be satisfied with their decision" (interview, 6 April 2018).

Authoritative Parents' Involvement in Public Schools

Cognisant of the relatively protective environment at Muslim-populated public schools, some authoritative parents mentioned a few side effects, such as the hardship in adapting to post-high school life. Jana, growing up in a Muslim-populated suburb, where she went to Muslim-populated schools, noticed the difference, especially in her job interviews: "I was dejected again, because it just hits you with the real world" (Jana, interview, 13 July 2018). Likewise, Jinan, sending her children to public schools in Muslim-populated suburbs, confessed her fear of not preparing her children for real life: "They're still in a very Islamic environment, so my fear of them is when they leave school" (interview, 6 April 2018).

Some parents took extra action to curb the side effects of public schooling by engaging them in sport activities where children would be exposed to different multicultural environments. Farkhunda involved her sons in soccer to "fuel their lives":

They were going really well at school, their outlet was soccer. They would have twice training, and they would have Saturday soccer. So that fuelled their life. We needed to fill their time with sports, rather than them fill their time with rubbish ... Two of them made it to youth league. So, I would be going from one corner of NSW to another, driving. I put in a lot of effort into my kids just so that I could support them so that they don't go off and do the wrong thing. (Farkhunda, interview, 18 December 2017)

Living and schooling her son in a Muslim-populated environment, Meliha similarly made extra efforts to immerse her son in the other cultures. Sports was similarly instrumental in such immersion:

... I exposed him to a lot of experiences outside of the school, meet non-Muslim people, like he used to go to the tennis, he used to go the swimming, like he used to go to tae kwon do in Cabramatta for instance, I exposed him to different things. Tennis was in the Eastern Suburbs out in Hornsby, so I exposed him to a lot of different nationalities and religious backgrounds, so when he went to university he had no problems, because he was already exposed to a lot of people. (Meliha, FGD, 15 November 2017)

Meliha observed her son's self-confidence as a young Muslim man who can easily socialise with any people from different backgrounds.

Another side effect of public schooling was Muslim children's exposure to different teachings, perspectives and philosophies that may contradict their religious values at home. Some parents did not "want them [their children] to shop around for the best answer" at school (Firdaus, interview, 10 December 2017). For instance, Firdaus told her children to ask her first, even before asking their teachers at school. Firdaus inserted a voice in the school by volunteering for scripture classes. Likewise, realising a gap in religious teaching, Sally started scripture classes for a handful of Muslim students at her daughter's school. No room for religion in public schools made some parents conscious of continually instilling 
their children with religious values. For instance, Firdaus explains the religious education routine at home:

We talk a lot at home, in terms of I'll give them lessons, after showers, you know I'll give them a taalim lesson and stories of the prophets. When we're driving to school, I'll also give them stories. (Firdaus, interview, 10 December 2017)

Authoritative parents sending their children to public schools filled the emerging gaps by taking extra steps, such as socialising their children in afterschool activities and teaching the children about the religion in scripture classes or at home.

\subsubsection{Authoritative Parenting-Upper End of the Spectrum}

Some parents exceeded a moderate authoritative attitude and became closer to permissive parenting by exposing their children to a wider variety but without losing parental control on their children's religious identity (Bright Horizons Education Team 2020). Those parents living away from Muslim-populated suburbs had to send their children to public schools where there were a few or no Muslims. Although these preferences cannot express the parental tolerance to foreign exposure, parents who deliberately made choices and expressed satisfaction with their children's school environment disclosed their authoritative parenting at the higher end of the spectrum, especially in relation to schooling.

Those parents limited with school variety in their local area opted for ethno-religiously diverse schools over Anglo-dominated schools. For instance, Sally, living in North Sydney, went out of her neighbourhood to find a school with a mixed student population. Eventually she found one, where only Sally and her daughter were wearing hijab.

Authoritative parents with permissive parenting tendencies expressed positive outcomes with sending their children to public schools with no Muslim presence. Growing up in the ACT decades ago when the Muslim presence was much less, Hayley interprets her children's similar experiences positively:

And now that they're growing up here, they didn't have many Muslims friends either, they had Italian friends, Greek friends, I just think that it is important to know, when they are growing up. So, they are able to talk with other people because they are going to go out in the workforce one day and they have to have the skills and they can't be, oh I hate Christians, I hate Jews. I don't want them to hate anyone, we have to represent who we are, not just in our dress sense. (Hayley, FGD, 15 December 2017)

Instead of focusing on the challenges of being an invisible minority in the school, Hayley highlights how this type of exposure taught her children to be real Muslims, which is meant to be by action and embracing other religions and cultures. Hayley similarly believes that exposure to a multicultural environment at school make children resilient as well.

Authoritative Parents in Charge of a Smooth Schooling Experience for their Children

Exposing their children to the school settings where Muslims are almost non-existent, faith-inspired authoritative parents similarly prefer nurturing empathy and love in other children towards their Muslim children and their religion. Such parental intervention by Muslim parents removes the discomfort for their children to express their Muslim identity while preventing racist bullying of their children at school.

Hijabi mothers used the love factor strategically to warm non-Muslim students to their and their daughters' hijab at school. As the only hijab-wearing mother-daughter couple in the school community, Sally ensures her daughter's hijab nicely matches her school uniform and looks "very presentable with it on". Eventually a lot of her friends told her they "think it's pretty, and that she looks like a nice princess with it on" (interview, 30 May 2018).

Likewise, in a remote NSW town where no Muslims live and difference is taken as a nice addition, Olivia tried to win over her daughter's friends and the school admin by 
taking part in all her daughter's events, interacting with her daughter's friends and is well-loved by them. Sally and Olivia make their daughters proud of their hijabi mothers. This also indicated the young girls' confidence in expressing their Muslim identity to the entire school community.

Empathy is another tool used by Muslim parents to raise awareness among nonMuslim students and avoid prejudice directed at their Muslim children. For instance, Sally talked to her daughter's friends who bullied her and pulled off her hijab.

I did come in and give them a little talk about what the hijab means, and why we wear it. And I did explain that Aisha has chosen to put this on, she does not need to wear it at this age, and sometimes she also doesn't wear it. (Sally, interview, 30 May 2018)

Realising that her hijab is a source of discomfort for her son, Farida and her Iraqi friend also decided to organise a hijab event at their children's school. Although the class teacher was initially hesitant, she felt obliged to talk about the topic to the class "if it is an issue". Farida gave a talk about the hijab while her Iraqi friend showed her "beautiful hairs" to the primary children:

... She took her hijab off and she had beautiful long hair and everybody, everybody was like mesmerised, especially the girls. Like "you have beautiful hair", I mean the topic changed to, hair, no one noticed the scarf, and no one noticed. So, from that day onward it just boosted up the kids and the other kids would tell, "oh they have beautiful hair, they have long hair", and that stops the conversation, which is good. (Farida, interview, 12 December 2017)

The same parents, in the absence of any awareness about Muslims, decided to organise a Muslim awareness week and fundraising for an Eid festival at school. They fostered understanding and appreciation of Islam by the entire school, including parents.

\subsection{Permissive Parenting}

Only one parent was willing to send her child to a school with no Muslim presence despite other schooling options. For her, religion was a private matter and should be taken out of the school context. Fearful of militant interpretations of Islam, this parent found religious education at home a safer option.

Farah, teaching at a tertiary-level education institution, internalised the secular position of public schools in Australia (Keddie et al. 2019). Yet, no room for religions at public schools denied the reality of ethno-religiously diverse societies' need for being recognised and accommodated in an inclusive schooling approach (Keddie et al. 2019). Farah was confronted by the fact that removal of religion from public schools is impossible as her son was verbally and physically bullied at school because of his Muslim identity. These continuous bullies scared Farah about her son's possible reaction to Muslims' stigmatisation by inclining to "certain groups and being pulled in [a] certain path" (interview, 1 August 2018). Consequently, Farah isolated her son from Muslim-populated schools and summer camps.

Surprisingly, while protective parents (like Mustafa) save their children from Islamophobic bullying by sending them to Islamic schools, permissive parents like Farah adopted an opposite solution to the same problem. Farah immersed her son in a completely foreign environment in a Catholic school with no Muslim presence. Further, she deliberately isolated her son from Islamic circles to protect him from militant interpretations of the religion.

Farah's immersive schooling approach aimed to show her son how real life would be outside school. According to Farah, schools are a place to be "exposed to [the people of] other faiths and other cultures ... It's a reality check; it's a shock to them [children], so it's very important for them to mix" (interview, 1 August 2018). 


\subsection{Custom-Made Parenting: Accommodating Children's Personalities}

Contrary to some research, Cahill (2009) found that accommodating children's needs at school is more valuable than meeting parental expectations. This is especially the case for some middle-class Muslim parents who prioritise their children's healthy sense of belonging and comfort in a school setting. Child-matching to a school according to the child's interests, needs, talents and/or personality is a typical middle-class parent attitude, and such parents are called 'skilled choosers' (Jamal Al-deen 2019, p. 167). The process of matching in such cases often results in different choices for each child (Jamal Al-deen 2019, p. 166). For instance, realising her child's low esteem, one Muslim parent in Jamal Al-deen's study (Jamal Al-deen 2019, p. 166) decided to switch to a more appropriate school, for which the parent sold her house to move to the suburb where the new school was located.

Jinan, who is a teacher and was recently admitted to a PhD program, also centralised her children's personality in her school choice: "Depending on their personality, I chose a school that would be suited to their personalities on purpose" (interview, 6 April 2018). Accordingly, she sent her three children to different schools, regardless of the logistic hardship embedded in her custom-made school choices. Accordingly, her son goes to a co-educational public high school, her elder daughter who chose to wear hijab and seek comfort and support goes to a girls' high school where the Muslim presence is significant but not dominant, while her younger daughter goes to a public primary school where Muslims are the majority population.

Despite being protective, Mustafa also expressed that his compass in school choice was his children's comfort:

They told me that they would rather go to an Islamic school, so I thought 'you know what, if they're more comfortable with going to an Islamic school, for whatever reasons, I'm more than happy also.' (Mustafa, interview, 5 December 2017)

Children's comfort was repeatedly mentioned by parents. Cahill emphases that "parents prefer schools to explicitly focus on and cater for the individuality of their children" (Cahill 2009, p. 124). This is especially the case for girls in high school who wear or are considering wearing hijab at high school. The hijab is a strong identifier and sometimes a strong incentive in drawing anti-Muslim hate behaviours and bullying. Therefore, girls' sense of comfort, especially in a school context, was a primary concern and some parents admitted it is sometimes related to the children's personality and how they handle it:

I said to my husband, we can't decide what school she's going to go to, it all depends on what type of person she is. I want her to feel comfortable, that if she wants to wear the scarf that she's among other people that wear the scarf. You can't just put her in somewhere where there isn't any [support]. I worry a lot about how the children are going to grow up and what kind of things they're going to face, because it's only getting worse. (Jinan, interview, 6 April 2018)

Like their parents, children's response to schooling options varies. The same conditions do not bear the same results for parents and children. While different parenting styles lead to varying results, children's differing personalities result in dissimilar experiences. Innately confident children and those confident in their Muslim identity, appreciate their difference and enjoy being the source of attention in Muslim-minority school settings. For instance, as the only hijabi student at school, Helena's daughter Carol likes being the reference point for all questions related to Muslims and the hijab. Helena explains "she [her daughter] felt proud educating non-Muslims about the scarf, which was the reason she wanted to wear it at a public school". Likewise, Sally's daughter, who is the only hijabi in an inner-city school, confidently coped with some verbal and physical bullying regardless of her young age. Sally explains her daughter's resilience with her strong character: "Aisha is quite strong. She doesn't take things too personal and she's happy to answer the questions". Some bullying about her hijab "wasn't distressing her" because she was not one of those "sensitive" girls. Similar to Helena and Sally, Olivia did not observe any 
trace of unease in her daughter's behaviours when Olivia was present at school as the only Muslim and hijabi mother because, according to Olivia, her daughter was "quite confident about who she is and who her family are". Olivia admits "we might look different, but I don't think that matters to her" (interview, 8 August 2019).

Some children who are less comfortable simply hid their Muslim identity as a practical survival strategy to be accepted by other children. Jana, who concealed her Muslim identity at school until wearing hijab at university, recalls her public-school life as being easy because of being unnoticed without a hijab.

Pretending to be like others in public school by hiding one's Muslim identity was observed not only in high school but also at kindergarten for some children. For instance, Farhana's daughter did not want to ask for an Eid break because she did not want her Muslim identity to be discovered by her teacher. Farhana interprets this childish thinking as a desire to be like the others and "part of the majority". Yet, her daughter's unease with her Muslim identity in a public-school setting invokes "parental fear for her future": What if her daughter asks her "not to come to school ... 'it's my fear that I can see it happening in the future"" (FGD, 12 November 2017).

For some children, internal unease with their Muslim identity did not diminish with the presence of other Muslim students at school. Noura's introvert children, who chose to be insignificant at school and confrontational at home due to Noura's authoritarian teachings of Islam, lost confidence and trust in their Muslim identity. For Noura, it was a wrong decision to send them to a public school. Some children could not cope with the diversity even within a relatively homogenous Islamic school setting. Asma and Razia switched from an Islamic school to home schooling, seeing their children confused between the home and school teachings. Likewise, Farah, who sent her son to a Catholic school and isolated him from Muslim students, admitted that full immersion into a foreign school environment was not the best idea for her son.

\section{Conclusions}

Although different studies introduced an extensive list of what Muslim parents in the cultural West would want from public or Islamic schools for their children, not much is said on the reasons behind the listed parental expectations from schools. Parenting styles, parental mentality, parents' own schooling experiences and children's particular personality type were indeed influential in parental school choice as the focus group discussions and interviews with Muslim parents highlight.

Contrary to the present literature, this study also introduced more diverse school options available to Muslim parents in the cultural West, such as Muslim-administered non-denominational schools, home schooling and varying public-school types whose characteristics were shaped by the demographics of their surrounding suburbs. The parental attitude towards the wide-ranging school options was diverse, although most of the parents came from a more or less similar background as educated, middle-class, faith-inspired moderate Muslim families. One of the most determining factors in parental school choice was parenting styles and mentality. As the literature suggested, the majority of the faith-inspired parents adopted authoritative parenting but within a wide spectrum getting sometimes closer to authoritarian or permissive parenting.

Nevertheless, all the parents expressed their children's similar needs under an Islamophobic climate such as feeling "safe", "comfortable", "belonged" and feeling "like the rest of the school". Some children's personalities were strong enough to reject feeling outlandish, while others felt uncomfortable and always sought students and staff members like themselves. Parents strived to find the right type of school for their children by using the right parenting style. The toll has been on the Muslim parents and their children as if anti-Muslim racism is not a structural and social but a community problem. In fact, schools in multicultural Australian settings are expected be compatible with its ethno-religiously diverse landscape. Ideally, schools should be the grounds for showcasing social cohesion by accepting and accommodating diversity as part of the mosaic in an 
everyday life setting (Markus 2016). As Islamophobic discourses are getting infused into the mainstream discourses, researching Muslim parents' experiences and obstacles with raising self-confident and successful Muslim children within the cultural Western and Australian schooling system becomes essential to inform social policies within the realm of education, curriculum design and schooling.

The studies on the parenting style of racialised minorities are relatively small. Additionally, in the absence of longitudinal studies, not much is known about the role of parenting style on racialised children. Likewise, not much is known about the impact of middle-class parental strategies of Muslim parents on raising self-esteemed children in the cultural West. The available data introduced in this paper imply that Muslim middle-class parents develop an intersectional parenting strategy considering the interplay of religion, race, class and gender. At this juncture, Muslim parents' prime concern is to raise resilient individuals equipped to resist Islamophobia and structural discrimination. Contrary to the common "inheritance" assumption, according to which children are born into a socioeconomically advantaged family and enjoy its benefits in future life, middle-class Muslim children are obliged to strive for building their own future by entering and surviving in the middle class as confident and able Muslim individuals. Accordingly, middle-class Muslim parents feel the pressure of finding the right school and equipping their children with the right in-community and out-community values and sentiments since the dominant culture, values and racialised structure operate to the detriment of ethno-religiously different minorities in the cultural West including Australia.

To sum up, school choice remains a critical decision for faith-inspired Muslim parents in the cultural West including Australia in the absence of policies designed for fostering integration at schools (Cucchiara and Horvat 2014, p. 486). Which school type best suits Muslim parents and their children remains a sophisticated question when all the aforementioned factors are taken into account. Consequently, there is no one size fits all.

Funding: Publishing this article was funded by the Open Access Publishing scheme by Charles Sturt University.

Institutional Review Board Statement: The study was conducted according to the guidelines of the National Statement on Ethical Conduct Human Research, and approved by the Charles Sturt University ethics board (Protocol: H19197) and the University of Western Australia ethics board (Protocol: RA/4/1/1651).

Informed Consent Statement: Informed consent was obtained from all subjects involved in the study.

Acknowledgments: Thanks to Sarah Redshaw for coding the data and reviewing the initial draft. A few articles she provided were instrumental for this article. Thanks to Azim Zahir for the first round of coding the data. Thanks to Linda Briskman and Samina Yasmeen for collaborating with me in a larger research project investigating Islamophobia and children in Western Australia, Victoria and New South Wales. Thanks to Emna Malas and Aminath Didi for their administrative support. Without their contribution, this article would be incomplete. Heartfelt thanks to all.

Conflicts of Interest: The author declares no conflict of interest.

\section{Notes}

1 The interstate study was conducted in collaboration with Samina Yasmeen of the University of Western Australia and Linda Briskman of Western Sydney University. This article focuses only on one leg of the study conducted in NSW.

\section{References}

Ahmad, Iftikar, and Michelle Y. Szpara. 2003. Muslim children in urban America: The New York City school experience. Journal of Muslim Minor Affairs 23: 295-301. [CrossRef]

Akbarzadeh, Shahram. 2016. The Muslim question in Australia: Islamophobia and Muslim alienation. Journal of Muslim Minority Affairs 36: 323-33. [CrossRef]

Baumrind, Diana. 1991. Effective parenting during the early adolescent transition. In Advances in Family Research Series: Family Transitions. Edited by Philip A. Cowan and E. Mavis Hetherington. Mahwah: Lawrence Erlbaum Associates, Inc., pp. 111-63. 
Bright Horizons Education Team. 2020. What Is My Parenting Style? Four Types of Parenting. Newton: Bright Horizons, Available online: https: / / www.brighthorizons.com/family-resources/parenting-style-four-types-of-parenting\#: \{\}:text=Indulgent $\% 20$ Parenting, problems\%20out\%20on\%20their\%20own (accessed on 7 September 2021).

Cahill, Rosemary. 2009. Factors That Influence the Decisions Parents Make When Choosing a Secondary School for Their Children. Ph.D. thesis, Edith Cowan University, Joondalup, Australia. Available online: https://ro.ecu.edu.au/theses/549/ (accessed on 7 September 2021).

Cheng, Jennifer E. 2017. Anti-Racist Discourse on Muslims in the Australian Parliament. New York: John Benjamins Publishing Company, vol. 72.

Clyne, Irene Donohue. 2001. Educating Muslim children in Australia. In Muslim Communities in Australia. Edited by Shahram Akbarzadeh and Abdullah Saeed. Sydney: UNSW Press, pp. 116-37.

Collins, Jock. 2007. The landmark of Cronulla. In Social Cohesion in Australia. Edited by James Jupp, John Nieuwenhuysen and Emma Dawson. Cambridge: Cambridge University Press, pp. 61-69.

Cucchiara, Maia Blookmfield, and Erin McNamara Horvat. 2014. Choosing selves: The salience of parental identity in the school choice process. Journal of Education Policy 29: 486-509. [CrossRef]

Skenderovic, Damir, and Christina Späti. 2019. From Orientalism to Islamophobia: Reflections, Confirmations, and Reservations. ReOrient 4: 130-43. [CrossRef]

Darling, Nancy, and Laurence Steinberg. 1993. Parenting style as context: An integrative model. Psychological Bulletin 113: 487-96. [CrossRef]

Department of Home Affairs. 2020. Australian Citizenship Statistics; Canberra: Australian Government. Available online: https: / / www.homeaffairs.gov.au/research-and-statistics / statistics/citizenship-statistics\#: \{\}:text=In\%202019\%2D20\%2C\%20 a\%20total,according\%20to\%20their\%20former\%20nationality (accessed on 7 September 2021).

Driessen, Geert, and Pim Valkenberg. 2000. Islamic schools in the Netherlands: Compromising between identity and quality? British Journal of Religious Education 23: 15-26. [CrossRef]

eSafety Commissioner. 2017. Online Hate, Bullying and Violence: Young People's Experience with Online Hate, Bullying and Violence; Canberra: Australian Government. Available online: https://www.esafety.gov.au/about-us/research/young-people-socialcohesion/ online-hate-bullying-violence (accessed on 7 September 2021).

Ghazala, E. Ahmed. 2013. Muslim parents at crossroads: Choosing the right school for their children/parent. Comparative and International Education 42: 4.

Hassan, Riaz. 2018. Australian Muslims: The Challenge of Islamophobia and Social Distance. Adelaide: International Centre for Muslim and non-Muslim Understanding, University of South Australia.

Ho, Christina. 2019. Ethnic Divides in Schooling. Sydney: Centre for Policy Development. Available online: https://cpd.org.au/wpcontent/uploads/2019/05/Ethnic-Divides.pdf (accessed on 7 September 2021).

Ho, Christina. 2020. Aspiration and Anxiety: Asian Migrants and Australian Schooling. Melbourne: Melbourne University Publishing.

Husain, Altaf. 2013. An Ecosystems-Based Model for Faith-Inspired Parenting. Journal of Human Behavior in the Social Environment 23: 159-70. [CrossRef]

Hutchinson, Jade. 2019. The new-far-right movement in Australia. Terrorism and Political Violence, 1-23. [CrossRef]

Iner, Derya, Nicole Asquith, Ho Leung Ip, Zahid Islam, Gail Mason, Matteo Vergani, and Iman Zayied. 2019. Islamophobia in Australia-II (2016-2017). Sydney: Charles Sturt University.

Jamal Al-deen, Taghreed Jamal. 2019. Motherhood, Education and Migration: Delving into Migrant Mothers' Involvement in Children's Education. Germany: Springer.

Jones, Peter. 2012. Islamic schools in Australia. The La Trobe Journal 89: 36-47.

Keddie, Amanda, Jane Wilkinson, Luke Howie, and Lucas Walsh. 2019. ' . . We don't bring religion into school': Issues of religious inclusion and social cohesion. The Australian Educational Researcher 46: 1-15. [CrossRef]

Khalifa, Muhammad, and Mark A. Gooden. 2010. Between resistance and assimilation: A critical examination of American Muslim educational behaviors in public school. The Journal of Negro Education 79: 308-23.

Lareau, Annette. 2002. Invisible inequality: Social class and childrearing in black families and white families. American Sociological Review 2002: 747-76. [CrossRef]

Markus, Andrew. 2016. Mapping Social Cohesion: The Scanlon Foundation Surveys 2016. Victoria: Monash University.

Markus, Andrew. 2018. Mapping Social Cohesion: The Scanlon Foundation Surveys 2018. Victoria: Monash University.

Martinez, Priscilla. 2009. Muslim Homeschooling. In Educating the Muslims of America. Edited by Yvonne Y. Haddad, Farid Senzai and James I. Smith. New York: Oxford University Press, pp. 109-22.

McAndrew, Marie. 2010. The Muslim community and education in Quebec: Controversies and mutual adaptation. Journal of International Migration and Integration/Revue de L'integration et de la Migration Internationale 11: 41-58. [CrossRef]

McCreery, Elaine, Liz Jones, and Rachel Holmes. 2007. Why do Muslim parents want Muslim schools? Early Years 27: 203-19. [CrossRef]

Merry, Michael S. 2005. Advocacy and involvement: The role of parents in Western Islamic schools. Religious Education 4: $374-85$. [CrossRef]

Miller, Charles. 2017. Australia's anti-Islam right in their own words. Text as data analysis of social media content. Australian Journal of Political Science 52: 383-401. [CrossRef] 
Molook, Roghanizad. 1990. Full-Time Muslim Schools in the United States: 1970-1990. Ph.D. thesis, University of Maryland, College Park, MD, USA.

O'Donoghue, Thomas A. 2000. Issues in primary and secondary education in Australia: Past, present, future. International Journal of Educational Reform 9: 50-58. [CrossRef]

OnePath Network. 2018. 2017 A Year in Review: Islam in the Media. Available online: https:/ / onepathnetwork.com/wp-content/ uploads/2018/07/OnePath_Islam_In_The_Media_Report.pdf (accessed on 7 September 2021).

Peucker, Mario, and Debra Smith. 2019. Conclusion: Making sense of the far-right in Australia. In The Far-Right in Contemporary Australia. Singapore: Palgrave Macmillan, pp. 215-26.

Poynting, Scott, and Linda Briskman. 2018. Islamophobia in Australia: From far-right deplorables to respectable liberals. Social Sciences 7: 213. [CrossRef]

Poynting, Scott, and Greg Noble. 2004. Living with Racism: The Experience and Reporting by Arab and Muslim Australians of Discrimination, Abuse and Violence Since 11 September 2001: Report to the Human Rights and Equal Opportunity Commission. Sydney: Centre for Cultural Research, University of Western Sydney.

Poynting, Scott, and Barbara Perry. 2007. Climates of hate: Media and state inspired victimisation of Muslims in Canada and Australia since 9/11. Current Issues in Criminal Justice 19: 151-71. [CrossRef]

Reay, Diane, Gill Crozier, and David James. 2011. White Middle-Class Identities and Urban Schooling. Berlin: Springer.

Shah, Saeeda. 2012. Muslim schools in secular societies: Persistence or resistance! British Journal of Religious Education 34: 51-65. [CrossRef]

Shakeel, M. Danish. 2018. Islamic schooling in the cultural West: A systematic review of the issues concerning school choice. Religions 9: 392-423. [CrossRef]

Sirin, Selcuk R., and Michelle Fine. 2007. Hyphenated selves: Muslim American youth negotiating identities on the fault lines of global conflict. Applied Development Science 11: 151-63. [CrossRef]

Soliman, Amira. 2016. Muslim Parents' Shared Viewpoints About US Public Schools: A Q Methodological Study. Doctoral dissertation, Long Island University, CW Post Center, Brooklyn, NY, USA.

Suliman, Rosemary, and Dennis M. McInerney. 2006. Motivational goals and school achievement: Lebanese-background students in south-western Sydney. Australian Journal of Education 50: 242-64. [CrossRef]

Vincent, Carol, Nicola Rollock, Stephen Ball, and David Gillborn. 2013. Raising middle-class black children: Parenting priorities, actions and strategies. Sociology 47: 427-42. [CrossRef]

Wolf, Patrick J. 2018. Programs Benefit Disadvantaged Students. Education Next. Retrieved November 26. Available online: https://www.educationnext.org/programs-benefit-disadvantaged-students-forum-private-school-choice/ (accessed on 7 September 2021).

Zine, Jasmin. 2001. Muslim youth in Canadian schools: Education and the politics of religious identity. Anthropology and Education Quarterly 32: 399-423. [CrossRef] 